\title{
COMPARISON OF THE ACTION OF STREPTOMYCIN, POLYMYXIN B, AUREOMYCIN AND CHLOROMYCETIN ON $H$. PERTUSSIS, H. PARAPERTUSSIS, H. INFLUENZAE AND FIVE ENTERIC STRAINS OF GRAM-NEGATIVE BACILLI ${ }^{1,2}$
}

\section{By HATTIE E. ALEXANDER, GRACE LEIDY, AND WINIFRED REDMAN \\ (From the Babies Hospital and the Department of Pediatrics, Columbia University College of Physicians and Surgeons)}

Our recent investigations (1) suggest that knowledge of two factors operating in vitro-speed of lethal action on sensitive cells and frequency of resistant mutants-offers a reliable basis for predicting the therapeutic efficacy of streptomycin against eight different species of gram-negative bacilli. The data are summarized in Table I. The organisms responsible for infections which have been successfully treated with streptomycin- $H$. influenzae, $E$. coli and $H$. pertussis-have a low incidence of mutants which resist the action of $25 \mathrm{mcg}$. (micrograms) and $100 \mathrm{mcg}$. of streptomycin per c.c. In addition, their sensitive cells are killed rapidly by concentrations of streptomycin safely maintained in body fluids $(10 \mathrm{mcg}$. per c.c.). On the other hand, in those infections in which streptomycin has not been found effective therapeutically a concentration of $10 \mathrm{mcg}$. per c.c. is not rapidly bactericidal for the sensitive cells, and the frequency of mutants resistant to $25 \mathrm{mcg}$. of streptomycin per c.c. is relatively high $-10,000$ to 100,000 times the rate of comparable mutants in successfully treated infections (Table I). In Shigella and $H$. parapertussis infections, in which streptomycin has not been clinically evaluated, one would predict success in the former and failure in the latter.

In an effort to improve therapeutic results in those infections in which streptomycin has failed therapeutically, either uniformly or as a result of emergence of resistance, three newer antibiotics - polymyxin B, aureomycin and chloromycetinhave been compared with streptomycin in their

1 Presented at the Second National Symposium on Recent Advances in Antibiotics Research held in Washington, D. C., April 11-12, 1949, under the auspices of the Antibiotics Study Section, National Institutes of Health, Public Health Service, Federal Security Agency.

2 The work reported in this communication was supported by grants from The Commonwealth Fund and The National Institutes of Health. action on the same eight species of gram-negative bacilli.

For this purpose three features of their activity have been studied:

1. The minimal concentrations of each agent needed to prevent growth completely over a 48hour incubation period. A 24-hour period was used for aureomycin for most organisms.

2. The nature of their action on the eight species-primarily bacteriostatic or bactericidal-and the speed of any lethal action.

3. Predictable limitation of their therapeutic efficacy as a result of emergence of resistance and their influence on streptomycin-resistant mutants.

\section{Minimal effective concentrations}

A simple in vitro test, which provided valuable information of streptomycin action on these species, has been used to study the influence of polymyxin B, aureomycin and chloromycetin. This procedure determined the lowest concentration which completely prevented the growth of an inoculum of one to ten million organisms on an optimal agar medium after 48 hours' incubation. Because of the alleged lability of aureomycin in vitro the minimal effective concentration of this agent was assessed at 24 hours.

The results are seen in Table II. It is apparent that those organisms which require more than 25 mcg. of streptomycin per c.c. to prevent completely growth under the circumstances described are the causes of infections which have not been treated successfully with streptomycin. Polymyxin B appears to be the most efficient of the four agents and the broadest in its action. Aureomycin and chloromycetin are about equal in their range of action; the growth of each of the eight bacterial species is completely prevented by less than 25 mcg. per c.c. save for Ps. aeruginosa; the majority exhibited a high degree of sensitivity. 
TABLE I

\begin{tabular}{|c|c|c|c|c|c|}
\hline \multirow[t]{2}{*}{ Species } & \multicolumn{3}{|c|}{$\begin{array}{l}\text { Frequency of hutants Resistant } \\
\text { to Concentrations of Streptomycin } \\
\text { meg. per c.c. }\end{array}$} & \multicolumn{2}{|c|}{$\begin{array}{l}\text { Speed of Lethal } \\
\text { Action }\end{array}$} \\
\hline & $25 \mathrm{mcg}$. & 100 meg. & $1000 \mathrm{neg}$. & 10 ncg. & $100 \mathrm{mcg}$ \\
\hline & per c.c. & per c.c. & per c.c. & per c.c. & per c.c. \\
\hline H· Influenzas & $10^{-11}$ & $10^{-11}$ & $10^{-11}$ & 2-6 hrs. & $10 \mathrm{~min}$. \\
\hline H. pertussis & $10^{-10_{t 0}-11}$ & $10^{-10_{t 0}-11}$ & $10^{-10_{t 0}-11}$ & $4-24$ hrs. & 2 hrs. \\
\hline B. $\operatorname{col} 1$ & $10^{-10}$ & $10^{-10}$ & $20^{-20}$ & 6 hrs. & $1 \mathbf{h r}$ \\
\hline Shigellae & $10^{-9}+0^{10}$ & $10^{-9} t 0_{0}-10$ & $10^{-10}$ & 4 hrs. & 1-2 hrs. \\
\hline Salmonellae & $10^{-6}+0^{-7}$ & $10^{-9}$ & $10^{-10_{t 0}-11}$ & o* & 2-t hrs. \\
\hline S. typhosa & $20^{-5} t_{0}-6$ & $10^{-8}$ & $10^{-1} 0_{t 0^{-11}}$ & 0 & -24 hrs. \\
\hline H. parapertuss1s & $10^{-6}$ & $10^{-8}$ & $10^{-20_{t 0}-11}$ & 0 & $>24 \mathrm{hrs}$ \\
\hline Ps. aeruginosa & $10^{-5} t 0^{-6}$ & $10^{-7}$ to $^{-8}$ & $10^{-10}$ & 0 & 4 hrs \\
\hline
\end{tabular}

* - Not primarily bactericidal

\section{Speed of lethal action}

Polymyxin B, aureomycin and chloromycetin have been compared with streptomycin in the speed of their lethal action on small populations (approximately 10,000 to 30,000 organisms per c.c.) in environments which will permit growth. After exposure to the antibiotics for two, six and

TABLE II

MIMIMAL EFFECTIVE CONCENTRATIONS OF
STREPTOMYCIN (SM), POLYMYXIN B (PMB),
CHLOROMYCETIN (CM), AND AUREOMYCIN (AM)
FOR 8 SPECIES OF GRAM NEGATIVE BACILLI

\begin{tabular}{|c|c|c|c|c|}
\hline \multirow{2}{*}{ SPECIES } & \multicolumn{4}{|c|}{ ANTIBIOTIC -meg/se. } \\
\hline & SM & PMB & $\mathrm{CM}$ & $A M^{*}$ \\
\hline H. WFLUENZAE & $1-3$ & 0.3 & 1 & $0.5-1$ \\
\hline H. PERTUSSIS & 3 & $1-5$ & 1 & 3 \\
\hline E.COLI & $7.5-25$ & $0.5-3$ & $5-<25$ & $5-<25$ \\
\hline SHIGELLAE & 25 & 1 & $3-10$ & $3-5$ \\
\hline SALMONELLAE & $.25-200$ & $1-5$ & 5 & $5-<25$ \\
\hline S.TYPHOSA & $25-75$ & 0.5 & $3-5$ & 3 \\
\hline AEPUGINOSA & $100-200$ & $1-3$ & $>100$ & 50 \\
\hline PARAPERTUSOLS & $>25$ & 5 & 3 & $5 \rightarrow 10$ \\
\hline
\end{tabular}

24 hours, samples of the broth cultures were examined for the number of viable organisms per c.c. by seeding into appropriate media in pour plate preparations after removal of any inhibitory concentration of the antibiotic, either through dilution or centrifuging and resuspending in normal broth. Table III presents the results on each of the eight species. The per cent of viable organisms remaining after exposure for six hours to two different concentrations of each of the antibiotics is listed.

It is apparent that streptomycin is primarily bactericidal in $10 \mathrm{mcg}$. per c.c. only against species for which it has been shown to be therapeutically effective. Polymyxin $B$ exerts a rapid lethal action in concentrations of both $1 \mathrm{mcg}$. and $10 \mathrm{mcg}$. per c.c. Cultures of all species save for 0.07 per cent in Salmonella were sterile after two hours; shorter exposure times have not been studied. Chloromycetin in $10 \mathrm{mcg}$. per c.c. exerts a more rapid bactericidal action against $H$. pertussis and $H$. parapertussis than does aureomycin; against $H$. influenzae and $S$. typhosa the two agents are equal in the speed of their lethal action. Both aureomycin and chloromycetin are bacteriostatic for all of the other species with the exception of Ps. aeruginosa; in a concentration of $100 \mathrm{mcg}$. per c.c. aureomycin exerts a greater lethal action than does chloromycetin. On the other hand the 
results of exposure for 24 hours, not listed here, show that stasis of growth by chloromycetin persists through 24 hours in cultures of all of these organisms save for Ps. aeruginosa, and the number of viable cells even decreases significantly, whereas the static effect of aureomycin is seen after 24 hours only against Shigella and $S$. typhosa; these results may only reflect the deterioration of aureomycin. However the persistence of bacteriostasis with some organisms suggests that other factors are playing a role.

$P s$. aeruginosa is not even inhibited by a sixhour exposure to streptomycin, chloromycetin or aureomycin in a concentration of $10 \mathrm{mcg}$. per c.c., whereas polymyxin B in a concentration of $1 \mathrm{mcg}$. per c.c. is bactericidal within two hours.

The greater bactericidal action of $100 \mathrm{mcg}$. per c.c. of streptomycin is worthy of emphasis since in infections of the meninges and urinary tract a comparable concentration can be maintained in these fluids without damage in most patients.

\section{Resistance problem}

The study of the limitation of therapeutic efficacy of these agents by the phenomenon of resistance was approached in two ways: 1 ) examination of large populations for presence of cells resistant to these antibiotics, and 2) examination of

TABLE III

\begin{tabular}{|c|c|c|c|c|c|c|c|c|}
\hline \multirow{3}{*}{ SPECIES } & \multirow{2}{*}{\multicolumn{2}{|c|}{$\frac{S M}{\operatorname{med} / / c c .}$}} & \multirow{2}{*}{\multicolumn{2}{|c|}{$\frac{P M B}{m e \phi / c e .}$}} & \multicolumn{2}{|c|}{ CM } & \multicolumn{2}{|c|}{$\mathbf{A M}$} \\
\hline & & & & & med & Ias. & mess & les. \\
\hline & 10 & 100 & 1 & 10 & 10 & 100 & 10 & 100 \\
\hline H. INFLUENZAE & 0 & 0 & 0 & 0 & 0 & 0 & 0.96 & 0 \\
\hline H.PERTUSSIS & 0.03 & 0 & & 0 & $\begin{array}{l}0.1 \\
2.0\end{array}$ & $\begin{array}{l}0.03 \\
3.0\end{array}$ & 10. & 0.1 \\
\hline E. COLI & 0 & 0 & 0 & 0 & 100 & $\begin{array}{l}52 \\
55\end{array}$ & 128 & 1.8 \\
\hline SHIGELLAE & 0 & 0 & 0 & 0 & 100 & $\begin{array}{l}65 \\
79\end{array}$ & 100 & 20 \\
\hline SALMONELLAE & $\begin{array}{l}1.4 \\
100\end{array}$ & 0 & 0.01 & 0 & 100 & $\begin{array}{l}26 . \\
35\end{array}$ & 100 & 8.6 \\
\hline S.TYPHOSA & $\begin{array}{l}37 \\
633\end{array}$ & $\begin{array}{l}0 \\
0.4\end{array}$ & 0 & 0 & $\begin{array}{l}54 . \\
60 .\end{array}$ & $\begin{array}{l}12 . \\
22 .\end{array}$ & 74 & 0.2 \\
\hline $\begin{array}{l}\text { PS. } \\
\text { AERUGINOSA }\end{array}$ & $\begin{array}{l}287 \\
1500\end{array}$ & 0 & 0 & 0 & 10,100 & 15 & 170 & 2.4 \\
\hline H.PARAPERTUSSIS & 100 & $\begin{array}{l}10 \\
25\end{array}$ & & 0 & $\begin{array}{l}0.4 \\
0.5\end{array}$ & 1.0 & 23. & $\begin{array}{c}0 \\
0.1\end{array}$ \\
\hline
\end{tabular}

TABLE IV

\begin{tabular}{|c|c|c|c|c|}
\hline \multicolumn{5}{|c|}{$\begin{array}{l}\text { MINIMAL EFFECTIVE CONCENTRATIONS OF } \\
\text { POLYMYXIN-B (PMB), CHLOROMYCETIN (CM), } \\
\text { AND AUREOMYCIN (AM) FOR STREPTOMYCIN } \\
\text { (SM) RESISTANT MUTANTS OF } 8 \text { SPECIES. }\end{array}$} \\
\hline \multirow{2}{*}{ SPECIES } & \multicolumn{4}{|c|}{ ANTIBIOTIC - megg/ec. } \\
\hline & $S M$ & PMB & CM & AM \\
\hline H. INFLUENZAE & $>1000$ & 0.1 & 1 & 0.5 \\
\hline H.PERTUSSIS & $>1000$ & 5 & 1 & 0.5 \\
\hline E.coll & $>1000$ & $0.3-3$ & $5-<25$ & $3-5$ \\
\hline SHIGELLAE & $>1000$ & 0.5 & 1 & $3-5$ \\
\hline SALMONELLAE & $>1000$ & $1-3$ & 5 & $3-5$ \\
\hline S.TYPHOSA & $>1.000$ & $0.3-0.5$ & 3 & 3 \\
\hline PS. & $>100$ & $1-3$ & $25->100$ & $3-<25$ \\
\hline PARAPERTUSSIS & $>1000$ & $5-25$ & $1-3$ & $1-3$ \\
\hline
\end{tabular}

their action on streptomycin-resistant mutants of each of these species.

It has already been reported $(2-4)$ that mutants resistant to $1000 \mathrm{mcg}$. of streptomycin per c.c. may be easily demonstrated in large populations of each of the eight species; mutants resistant to 25 $\mathrm{mcg}$. and $100 \mathrm{mcg}$. of streptomycin per c.c. are uniformly present in smaller populations of the species against which this antibiotic has not been effective therapeutically (1).

Large populations, 60 to 600 billions, of each of the eight species have been examined for presence of cells resistant to polymyxin $B, 10 \mathrm{mcg}$. and 100 mcg. per c.c. and chloromycetin $10 \mathrm{mcg}$. per c.c.; the supply has not permitted study of a higher concentration. $H$. pertussis and $H$. parapertussis have been examined for cells resistant to $10 \mathrm{mcg}$. and $100 \mathrm{mcg}$. of aureomycin per c.c.

It was not possible to demonstrate cells resistant to $100 \mathrm{mcg}$. per c.c. of polymyxin $\mathrm{B}$ in any species by this method, and only in Salmonella and $P s$. aeruginosa was it possible to demonstrate a minute fraction of cells resistant to $10 \mathrm{mcg}$. per c.c. ; when a few of the colonies of these two species which formed in agar containing $10 \mathrm{mcg}$. per c.c. were tested for their sensitivity to this concentration only an occasional colony grew in polymyxin B agar (10 mcg. per c.c.) but growth was normal on control medium. 
While a few colonies grew when large populations of $E$. coli, Salmonella and $S$. typhosa were seeded in pour plate preparations of agar containing $10 \mathrm{mcg}$. per c.c. of chloromycetin, none of them on subculture grew on chloromycetin agar (10 mcg. per c.c.).

The investigation of resistance of these newer agents is still in progress but it is already apparent that resistance to polymyxin $\mathrm{B}$ and chloromycetin differs from streptomycin resistance; the data suggest that emergence of resistance will play a less important role in therapy.

The influence of polymyxin $\mathrm{B}$, chloromycetin and aureomycin on cells highly resistant to streptomycin is shown in Table IV for each of the eight species. The sensitivity of these streptomycinresistant strains does not differ significantly from those strains which are sensitive to streptomycin. Therefore it is apparent that the mechanism of action of each of these agents differs from the mode of action of streptomycin.

These data suggest a number of clinical applications. Polymyxin B would be the treatment of choice for all of these infections, but its toxic action precludes its clinical use unless the injurious substance can be removed without altering the antibacterial action. A final assessment of aureomycin in vitro must await additional factual data. Chloromycetin because of absence of toxic manifestations, its rapid lethal action on $H$. influenzae and $H$. pertussis and the rarity of resistant mutants warrants a clinical trial in these infections. In $E$. coli and Shigella infections there is reason to anticipate a more rapid elimination of the organisms by the combined action of sulfadiazine and streptomycin than by aureomycin or chloromycetin alone. In Salmonella and $S$, typhosa infections, either chloromycetin or aureomycin should be a more effective agent than streptomycin. For $P$ s. aeruginosa infections we can expect little therapeutic value from streptomycin, aureomycin or chloromycetin used as a single agent if concentrations in the body fluids do not exceed $10 \mathrm{mcg}$. per c.c. The results suggest that the combined action of streptomycin and aureomycin may prove of therapeutic value in Ps. aeruginosa infections of body fluids in which concentrations of $50 \mathrm{mcg}$. to 100 mcg. per c.c. can be maintained with safety. In $H$. parapertussis infections chloromycetin should prove to be the treatment of choice.

\section{BIBLIOGRAPHY}

1. Alexander, H. E., Leidy, G., Redman, W., and Simakow, E., Experimental basis for prediction of therapeutic efficacy of streptomycin in infections caused by gram negative bacilli. Pediatrics (In press).

2. Alexander, H. E., and Leidy, G., Mode of action of streptomycin on type b Hemophilus influenzae. II. Nature of resistant variants. J. Exper. Med., $1947,85,607$.

3. Alexander, H. E., and Leidy, G., Mechanism of emergence of resistance to streptomycin in five species of gram negative bacilli. Pediatrics (In press).

4. Alexander, H. E., and Redman, W., Mechanism of emergence of resistance to streptomycin of $H$. pertussis and $H$. parapertussis during treatment with this antibiotic. Pediatrics (In press). 